\title{
PEMAKNAAN SUAMI TENTANG BURUH MIGRAN PEREMPUAN: STUDI KASUS DI KABUPATEN INDRAMAYU
}

\author{
Oleh: \\ Slamet Mulyana dan Teddy Kurnia Wirakusumah \\ Dosen Program Studi Manajemen Komunikasi Fikom Unpad
}

\begin{abstract}
ABSTRAK
Pengambilan keputusan migrasi adalah proses besar dalam keluarga buruh migran, khususnya suami bersama istrinya. Pilihan mengizinkan istri menjadi buruh migran di luar negeri telah membawa dampak terhadap relasi domestik yang terjadi dalam keluarga, termasuk di dalamnya relasi suami-istri, relasi suami-anak, relasi istri-anak. Tujuan penelitian ini adalah menjelaskan pemaknaan subjektif suami tentang buruh migran perempuan, yang dilihat dari persepsi suami yang informan mengenai 'istri yang menjadi buruh migran' serta persepsi suami informan terhadap pandangan-pandangan orang lain tentang 'istri menjadi buruh migran'.

Penelitian ini menggunakan pendekatan kualitatif dengan metode studi kasus. Lokasi penelitian di Kecamatan Sliyeg Kabupaten Indramayu dengan narasumber dipilih secara purposif adalah suami yang istrinya sedang atau pernah menjadi buruh migran di luar negeri. Hasil penelitian menunjukkan bahwa persepsi suami yang menjadi informan mengenai "istri yang menjadi buruh migran' bervariasi dari mulai istri menjadi buruh migran adalah pilihan yang baik, kemudian pilihan yang biasa-biasa saja, dan pilihan yang terpaksa dilakukan. Sementara persepsi suami informan terhadap pandangan orang lain tentang 'istri menjadi buruh migran' juga bervariasi dari mulai pandangan orang lain tentang istri menjadi buruh migran adalah pandangan yang biasa saja, pandangan orang lain merupakan kritik sekaligus sebagai masukan yang berharga, dan pandangan yang seringkali membuat kesal.
\end{abstract}

Kata Kunci: makna subjektif, buruh migran perempuan, persepsi, keputusan migrasi.

\section{Pendahuluan}

Menjadi buruh migran adalah pilihan yang banyak diambil oleh warga perempuan di Kecamatan Sliyeg Indramayu, di mana sebagian besar di antaranya (sekitar 70\%) dilakukan oleh perempuan yang sudah bersuami. Pilihan yang penuh resiko tersebut dipersepsi beragam oleh masyarakat, bahkan oleh suaminya sendiri. Pengambilan keputusan migrasi adalah proses besar dalam keluarga buruh migran, khususnya suami bersama istrinya.

Mereka memutuskan sesuatu yang akan berpengaruh terhadap kehidupan keluarganya beberapa tahun ke depan. Keputusan migrasi secara tidak langsung menggeser pekerjaan istri dari sektor domestik ke sektor publik; telah mengubah peran perempuan dari peran reproduksi menjadi produksi. Hal ini sekaligus akan memberikan dampak yang besar terhadap peran dan 
fungsi perempuan dalam keluarga. Keputusan migrasi akan menimbulkan friksi dengan nilai dan kultur yang ada di masyarakat pedesaan.

Penelitian Rosadi (2010), dalam disertasi doktoralnya yang berjudul "Konsekuensi Migrasi Internasional terhadap Relasi Gender (Studi tentang Buruh Migran Internasional yang Pulang dari Bekerja di Luar Negeri di Kecamatan Juntinyuat, Kabupaten Indramayu Jawa Barat), menunjukkan bahwa pengalaman migrasi internasional para buruh migran perempuan membawa konsekuensi berubahnya hubungan sosial di dalam keluarga. Perubahan itu terutama pada relasi gender yang mengarah pada kesetaraan antara laki-laki dan perempuan.

Perubahan relasi gender dalam keluarga buruh migran internasional yang kembali dari bekerja luar negeri, terletak pada aspek perubahan peran (yang mengarah kepada berbagi peran), perubahan akses perempuan (yang makin lebih besar kepada perempuan untuk menjangkau kesempatan bekerja dan melakukan aktivitas di luar rumah) serta pergeseran dalam kontrol (mulai ada berbagi kendali dalam kehidupan keluarga antara perempuan/istri dan laki-laki/suami). Perubahan relasi gender itu dimaknai sebagai konsekuensi yang tidak dikehendaki (unintended consequences) dari migrasi internasional, yang juga berkaitan dengan adanya konsekuensi sosial yang bersifat ongkos sosial (social cost) dari migrasi internasional.

Penelitian tersebut menunjukkan bahwa keputusan menjadi buruh migran internasional, yang dalam penelitian ini banyak menjadi pilihan kaum wanita di Indramayu, menyebabkan perubahan-perubahan dalam relasi internal dan eksternal dalam keluarga. Indramayu adalah salah satu kabupaten di Provinsi Jawa Barat yang paling banyak mengirimkan tenaga kerjanya sebagai buruh migran ke luar negeri, di mana sebagian besar adalah burh migran perempuan, khususnya ke wilayah Timur Tengah dan Timur Jauh. Data kuantitatif menunjukkan secara nasional, Kabupaten Indramayu menempati posisi pertama sebagai daerah yang paling banyak mengirimkan buruh migran.

Fenomena pengiriman buruh migran perempuan ke beberapa negara sebenarnya tidak terlepas dari adanya gelombang feminisasi migrasi. Dalam beberapa dekade terakhir, terjadi lonjakan gelombang migrasi dimana sebagian besar pergerakan tenaga kerja didominasi oleh perempuan. Untuk kasus Indonesia sendiri, sekitar $75 \%$ dari jumlah keseluruhan buruh migran yang dikirimkan ke berbagai negara adalah perempuan (Susilowati, 2011: 153). Feminisasi migrasi ini sendiri dipicu lantaran jenis permintaan tenaga kerja di beberapa negara yang lebih membutuhkan tenaga kerja non-skilled untuk dipekerjakan di sektor domestik, khususnya sebagai pekerja rumah tangga (PRT). 
Di sisi lain, keputusan perempuan menjadi buruh migran juga berkaitan dengan keberadaan keluarga (khususnya pihak laki-laki) sebagai significant others. Dalam hal ini, significant others adalah orang-orang terdekat yang dianggap penting (Rakhmat, 2005). Dalam kasus buruh migran perempuan, orang tua atau saudara laki-laki sebagai significant others seharusnya menjaga dan melindungi anak atau saudara perempuannya; suami juga berkewajiban tidak hanya menjaga dan melindungi istrinya, tetapi juga memberikan nafkah lahir dan batin bagi istri atau keluarganya.

Tujuan penelitian ini adalah menjelaskan pemaknaan suami tentang buruh migran perempuan. Dalam hal ini, pemaknaan berkenaan dengan persepsi suami yang menjadi informan penelitian mengenai “istri yang menjadi buruh migran' serta persepsi suami informan terhadap pandangan-pandangan orang lain tentang 'istri menjadi buruh migran'. Realitas tentang buruh migran perempuan sebagai realitas sosial adalah suatu realitas subjektif; realitas yang antara lain dikonstruksi oleh para suami yang istrinya menjadi buruh migran. Walaupun realitas sosial tentang buruh migran perempuan secara objektif diakui memang ada tetapi maknanya berasal dari dan oleh hubungan subjektif (individu) dengan dunia objektifnya; hubungan subjektif antara suami buruh migran dengan dunia sosialnya, termasuk dengan istrinya yang menjadi buruh migran.

Realitas terbentuk secara sosial, sehingga pemahaman tentang realitas sosial itu sendiri dapat dilakukan dengan jalan menganalisis proses bagaimana realitas sosial itu terjadi. Di sini diakui adanya realitas objektif dengan membatasi realitas sebagai realitas yang berkaitan dengan fenomena yang dianggap berada di luar kemauan individu (Berger \& Luckman, 1969). Oleh karena itu, realitas sosial harus dipahami secara substansial, sehingga kita harus berupaya mengerti atau memahami 'makna' (meaning) yang mendasari dan atau melingkupi suatu realitas sosial secara utuh dan holistik.

Dengan pemahaman semacam ini, realitas berwajah ganda/plural. Setiap orang bisa mempunyai konstruksi yang berbeda-beda atas suatu realitas. Setiap individu yang mempunyai pengalaman, preferensi, pendidikan tertentu, dan lingkungan pergaulan atau sosial tertentu akan menafsirkan realitas sosial itu dengan konstruksinya masing-masing.

\section{Metode dan Teknik Penelitian}

Penelitian ini menggunakan pendekatan kualitatif dengan metode studi kasus. Pendekatan kualitatif digunakan karena tujuan dari penelitian ini menghendaki adanya pernbahasan yang holistik, sistemik, dan mengungkapkan makna dibalik fakta empiris 
mengenai pemaknaan suami tentang buruh migran perempuan. Metode studi kasus digunakan dengan mempertimbangkan relevansinya untuk menelaah sebanyak mungkin data mengenai subjek yang diteliti, yaitu pemaknaan suami tentang buruh migran perempuan. Dalam studi kasus, peneliti mempelajari sebanyak mungkin data mengenai seorang individu, kelompok atau suatu kejadian, peneliti bertujuan memberikan pandangan yang lengkap dan mendalam mengenai subjek yang diteliti (Mulyana, 2001: 201). Studi kasus merupakan penelitian yang mempelajari secara intensif atau mendalam satu anggota dari kelompok sasaran suatu subjek penelitian (Cresswell, 1998).

Pada penelitian ini yang menjadi narasumber atau key informan dan dipilih secara purposif adalah kepala keluarga (suami) yang istrinya sedang atau pernah menjadi buruh migran di luar negeri. Pengumpulan data diperoleh melalui wawancara dan observasi dari key informan sebanyak 16 orang kepala keluarga buruh migran. Lokasi penelitian adalah Kecamtan Sliyeg Kabupaten Indramayu, yang ditetapkan secara purposif sebagai salah satu wilayah kasus terbanyak. Data penelitian diperoleh dari hasil wawancara dan observasi langsung yang peneliti lakukan. Selain itu juga, dilakukan peninjauan ulang dan penggunaan dokumentasi dengan menyandarkan pada konsep konsep teoritis yang telah dijelaskan sebelumnya.

\section{Hasil Penelitian dan Pembahasan}

Bagaimana suami, sebagai informan penelitian, memaknai realitas mengenai buruh migran perempuan? Dalam penelitian ini, pemaknaan yang dimaksud berkenaan dengan persepsi suami informan mengenai "istri yang menjadi buruh migran" serta persepsi suami informan terhadap pandangan-pandangan orang lain tentang "istri menjadi buruh migran".

\section{Persepsi Informan tentang “Istri menjadi Buruh Migran"}

Persepsi informan tentang istri menjadi buruh migran dimaksudkan sebagai pemaknaan suami sebagai informan berdasarkan pengalaman-pengalaman subjektifnya mengenai keberadaan istrinya yang saat sedang menjadi buruh migran. Jawaban yang muncul dari informan terkait pertanyaan tersebut terlihat pada diagram 1. berikut: 


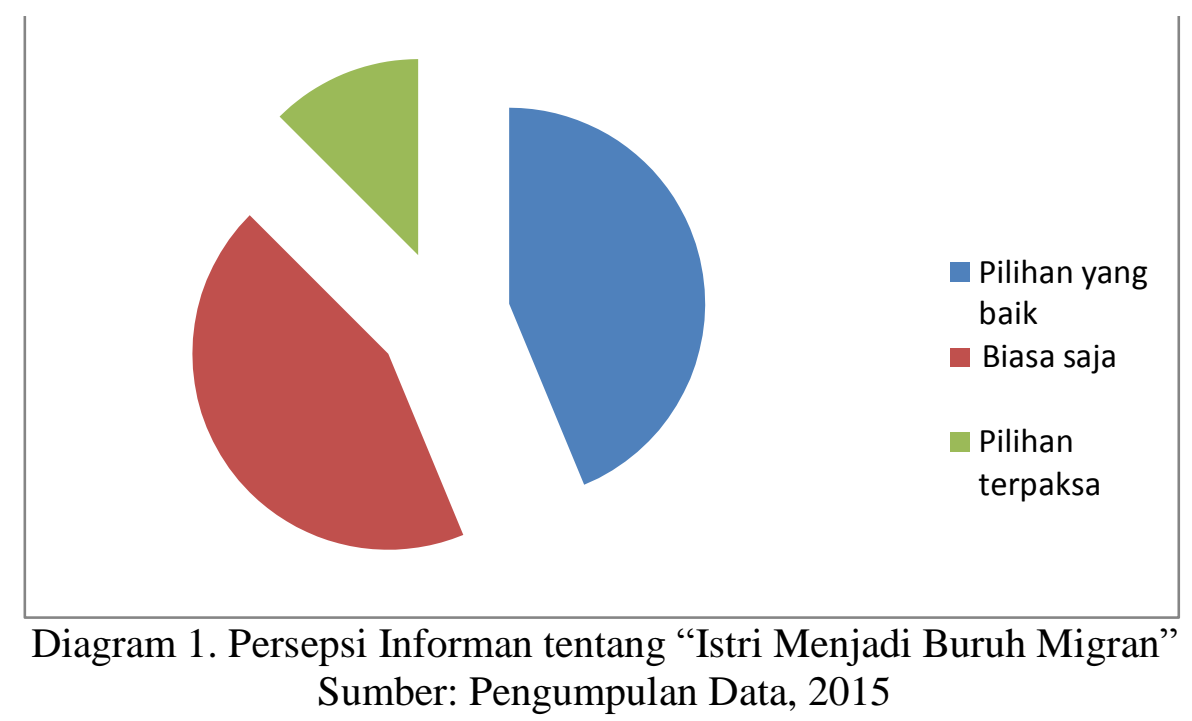

Data pada diagram 1. menunjukkan adanya tiga variasi jawaban di mana dari seluruh informan penelitian (16 orang), terdapat 7 orang yang menyatakan bahwa istri menjadi buruh migran adalah pilihan yang baik, kemudian 7 orang menjawab sebagai pilihan yang biasabiasa saja, dan terakhir 2 orang menyatakan sebagai pilihan yang terpaksa dilakukan.

\section{a. Pilihan Yang Baik}

Bagi banyak warga Kecamatan Sliyeg Indramayu, khususnya bagi sebagian informan, keputusan mengizinkan istri menjadi buruh migran dimaknai sebagai pilihan keputusan yang baik dari beberapa pilihan yang ada. Situasi dan kondisi yang ada membuat pilihan istri menjadi buruh migran merupakan alternatif solutif bagi mereka untuk bangkit dari himpitan kesulitan ekonomi.

Kalau memungkinkan beberapa dari informan mengatakan bahwa lebih baik dirinya yang menjadi buruh migran, tetapi persyaratan yang dibutuhkan untuk laki-laki agar bisa menjadi buruh migran sangat sulit dan merepotkan bagi mereka. Peluang untuk laki-laki berangkat jadi buruh migran bisa dikatakan sangat kecil mengingat rata-rata tingkat pendidikan dan keterampilan yang dimiliki. Sedangkan jika untuk perempuan, persyaratannya memamng sangat mudah, yang penting mau dan mempunyai biaya awal untuk berangkat. Jawaban salah satu informan, yaitu Sl, bisa mewakili jawaban informan lain,

“...jadi TKW, buat perempuan di sini memang gampang, kasarnya asal mau dan ounya biaya. Beda dengan laki-laki, ribet banget, harus bisa ini, bisa itu...pokoknya susah. Makanya di sini banyak perempuan yang jadi TKW...ya gimana lagi...." 
Selain itu, istri menjadi buruh migran dimaknai sebagai pilihan yang baik dikarenakan pilihan tersebut merupakan pilihan independen, tidak bergantung dan tidak merepotkan orang lain, yang keputusannya berada di tangan suami dan istri. Maksud dari pernyataan ini adalah pilihan 'istri menjadi buruh migran' adalah pilihan masing-masing keluarga di mana segala sesuatunya (masalah, resiko, dan sebagainya) merupakan tanggung jawab keluarga tersebut. Pernyataan informan lain yaitu Nrd bisa mewakilinya,

“...kata kula sih terserah masing-masing, mau gimana gitu. Jadi TKW kan maksudnya kan baik, caranya juga, baik ya mudah-mudahan hasilnya juga baik. Yang penting ga merepotkan wong liane, tanggung jawab masing-masing lah..."

Selain itu, sebagai alasan atau pertimbangan terakhir, yang membuat sebagian informan memaknai istri menjadi buruh migran sebagai pilihan yang baik ada kaitannya dengan budaya luruh duit. Di kalangan masyarakat Indramayu dikenal budaya luruh duit, yaitu budaya mencari duit dengan cepat dan mudah bagaimana pun caranya, bahkan dengan menjual diri (melacurkan diri/menjadi PSK) sekalipun.

Tradisi ngelanang dan ngadongdot adalah bagian dari budaya luruh duit tersebut. Ngelanang adalah menawarkan diri (secara fisik) kepada laki-laki untuk memperoleh imbalan materi, sedangkan ngadongdot adalah menggoda laki-laki kaya, berduit, agar tertarik. Ngelanang sudah pasti berorientasi seksual, sedangkan ngadongdot belum tentu berakhir dengan aktivitas seksual. Ngelanang dan ngadongdot juga dilakukan perempuan bersuami, bahkan banyak kasus menunjukkan hal itu dilakukan dengan seizin suami. Dalam sepuluh tahun terakhir pelaku luhur duit memang semakin berkurang, dan sebagian bergeser dengan menjadi buruh migran.

Informan menyatakan bahwa istri menjadi buruh migran merupakan pilihan yang jauh lebih baik dibandingkan dengan ngelanang atau ngadongdot. Walaupun dari sisi penghasilan jauh lebih kecil, menjadi buruh migran merupakan pilihan yang lebih terhormat. Berkenaan denga hal itu, Njy menyatakan sebagai berikut"

“...sampai sekarang, masih ada warga di Indramayu yang jalanin luruh duit, terutama di wilayah Pantura (Indramayu bagian utara), katanya sih semakin kurang. Kula sih ga mau seperti itu, apa pun alasannya ga baik....bojoku jadi TKW jauh lebih baik, ga jadi omongan wong kampung...hasilnya juga jadi, asal bisa ngatur..."

\section{b. Pilihan Biasa}

Sebagian informan yang lain (ada 7 orang) menyatakan bahwa istri menjadi buruh migran adalah pilihan yang biasa-biasa saja. Maksud pemaknaan mereka adalah bahwa istri 
menjadi buruh migran adalah pilihan yang tidak berbeda dengan pilihan pekerjaan yang lainnya. Kalaupun ada prosedur administrasi atau hal lain termasuk resiko dari menjadi buruh migran, itu sama saja dengan pekerjaan lain yang juga ada prosedur, masalah, dan resiko yang harus dihadapi.

Kajian-kajian tentang buruh migran perempuan sudah banyak menunjukkan beberapa masalah dan resiko dari menjadi buruh migran, dari mulai proses pra pemberangkatan (pendaftaran dan perekrutan), pemberangkatan, penempatan sampai kepulangan (Rahayu, 2011). Masalah tersebut antara lain dokumen yang tidak lengkap, dokumen palsu, penipuan oleh sponsor, korban pemerasan oknum, penempatan yang tidak sesuai kontrak, majikan yang galakdan kejam, gaji dipotong sponsor, gaji tidak dibayar sampai menjadi korban pelecehan seksual dan menjadi korban trafficking.

Masalah-masalah tersebut sudah banyak diketahui oleh buruh migran di Kecamatan Sliyeg Indramayu, termasuk oleh informan. Menurut informan, masalah tersebut memang bisa dihadapai oleh buruh migran, tetapi maslah tersebut bisa dihindari jika dilakukan dengan benar.Yang dimaksud dengan benar adalah mereka belajar dari orang-orang yang sebelumnya telah berhasil.

Beberapa pernyataan dan jawaban responden tentang pilihan jawaban istri menjadi buruh migran adalah biasa saja dapat disimak dari beberapa kutipan berikut:

“...bojoku jadi TKW ya biasa saja lah, toh banyak perempuan di sini yang juga jadi TKW, itu sudah lama, sudah bertahun-tahun...Paling yang dapat masalah ya beberapa...kali sudah takdirnya begitu..."

“...bagi kula sih ga ada masalah, biasa-biasa aja. Kerja apa pun pasti ada resikonya, gede atau kecil...ya tetep masalah. Kita bisa tanya-tanya ke orang, yang udah pergi duluan, jadi TKW juga, kan di sini banyak banget...banyak yang udah jadi..."

“...ya kita pasrah aja...sama Gusti Allah, ya mudah-mudahan bojoku ga dapat masalah kerja di tanah sabrang...”

Dari jawaban-jawaban tersebut terlihat bahwa masalah dari pilihan istri menjadi buruh migran adalah sesuatu yang akan dihadapi dan mereka siap dengan resiko tersebut. Mereka melihat dari sekian banyak warga yang berangkat menjadi buruh migran, jauh lebih banyak yang berhasil daripada yang gagal. Kalau pun gagal, dalam artian mengalami salah satu masalah seperti disebutkan sebelumnya, mereka mengatakan dan menerima halitu sebagai sebuah takdir, sudah digariskan oleh Gusti Allah. Dalam hal ini, terlihat adanya kepasrahan menerima takdir termasuk ketika bekerja sebagai buruh migran. 


\section{c. Pilihan Terpaksa}

Berdasarkan data pada diagram 1. terlihat bahwa pilihan terakhir yang menyatakan pandangan bahwa istri menjadi buruh migran adalah pilihan yang terpaksa dilakukan. Ada dua informan, yaitu Skd dari Tugu Kidul dan Srm dari Majasari, yang menjawab dan memilih alternatif ketiga ini. Pernyataan mereka didasari pertimbangan bahwa istri menjadi buruh migran adalah pilhan yang mempunyai resiko cukup berat buat mereka, khususnya berkaitan dengan kondisi internal keluarga yang sedang menghadapi masalah dan perlu segera dicari penyelesaiannya.

Istri menjadi buruh migran di luar negeri dalam waktu yang lama bisa mengancam keutuhan dan keharmonisan keluarga. Demikian kira-kira alasan yang dikemukakan Srm. Ia, yang merupakan informan yang usianya paling muda (29 tahun) memiliki istri yang usianya berbeda satu tahun, menyatakan bahwa berpisah dengan istri dirasakan sangat berat.Sudah hampir sembilan tahun mereka menikah dan dikaruniai satu orang anak. Istrinya berangkat menjadi buruh migran ketika anak mereka belum genap berusia dua tahun. Karena tuntutan keadaan istrinya sudah menjadi buruh migran untuk kontrak yang ketiga dan saat ini berada di Korea Selatan.

Menurut Srm, kepergian istrinya seperti itu membuat kebersamaan sebagai suami istri belum pernah mereka rasakan dengan semestinya sebagaiman keluarga lainnya. Berkenaan dengan kondisinya, Srm menceritakan'kisah'nya sebagai berikut:

“...Kula karo bojoku nikah tahun 2005, langsung punya anak. Akhir 2007 bojoku jadi TKW, terpaksa karena kondisi, Pak! Berat memang, anakku masih kecil lagi ...tapi gimana lagi. Karena masih butuh duit bojoku berangkat lagi, sudah kontrak ketiga. Kula ingin ini kontrak terakhir, kayaknya bentar lagi. Kula karo bojoku ingin kumpul, ga enak pisah terus... biar ga ada masalah lagi..."

Pilihan yang sama dilakukan Skd tetapi dengan alasan dan pertimbangan yang agak berbeda. Skd adalah informan yang merasakan bahwa hidupnya kurang beruntung. Ia dan istrinya mempunyai dua anak, yang saat ini sudah menginjak remaja. Sejak sakit, pernah dirawat karena terserang demam berdarah, Skd merasa kondisi fisiknya tidak memungkinkan ia bekerja terlalu capek sehingga pekerjaannya jadi tidak optimal dan penghasilannya pun seringkali pas-pasan. Karena kondisinya beberapa kali ia sempat berselisih dengan istrinya, lebih banyak karena alasan ekonomi; ia salah satu informan yang kehidupan keluarganya kurang

harmonis. 
Sejak awal ia memang terpaksa mengizinkan istrinya menjadi buruh migran karena punya utang biaya perawatan anaknya dan dirinya di rumah sakit. Setelah kontrak pertama berakhir, ia juga terpaksa mengizinkan istrinya berangkat lagi karena utangnya masih juga belum lunas. Ia selalu berharap ini kontrak yang terakhir bagi istrinya, akan tetapi kondisi terus memaksa ia menyetujui keberangkatan yang ketiga dan sekarang yang keempat. Sebagian gambaran tentang kisah Skd bisa disimak dari kutipan berikut:

“...kula sih pinginnya kayak wong lian, kumpul karo bojo, tapi sulit, ga mungkin saat ini. Awak kula cepet cape, sejak sakit, kerja jadi ga bener. Untung anak-anak dah gede. Pinginnya bojoku ada...tapi gimana ya...mudah-mudahan setelah ini ...segalanya selesai, dah cape, Pak!..."

\section{Persepsi Informan terhadap Pandangan Orang Lain tentang "Istri Menjadi Buruh Migran"}

Sejalan dengan asumsi dalam teori konstruksi sosial, bahwa manusia yang hidup dalam konteks sosial tertentu melakukan proses interaksi secara simultan dengan lingkungan sosialnya. Berdasarkan hasil proses interaksi sosial tersebut manusia akan memaknai berbagai realitas sosial sesuai dengan pengalaman-pengalaman subjektifnya. Bagi suami buruh migran di Kecamatan Sliyeg Indramayu, interaksi sosial mereka dengan teman atau tetangga akan memperkuat pengalaman tentang realitas sosial yang ada, termasuk tentang keberadaan istrinya yang menjadi buruh migran.

Persepsi informan terhadap pendapat orang lain tentang istri menjadi buruh migran dimaksudkan sebagai pemaknaan suami sebagai informan berdasarkan pengalamanpengalaman subjektifnya, terutama ketika ia berinteraksi dengan lingkungan sosialnya, mengenai berbagai pendapat atau persepsi atau pandangan orang lain seperti tetangga ataupun teman tentang keberadaan istrinya yang saat sedang menjadi buruh migran. Dalam hal ini, pandangan orang lain bisa saja merupakan pandangan yang medukung tetapi juga bisa merupakan pandangan yang mencibir atau melecehkan.

Suami buruh migran sebagai subjek memiliki cara tersendiri, keunikan, dalam memaknai setiap hal yang berasal dari lingkungan. Keberadaan orang, nilai, aturan atau otoritas status atau hal lainnya yang merupakan bagian dari lingkungan akan dimaknai berdasarkan kerangka berpikir mereka, tanpa mempertimbangkan makna baku yang mungkin sudah berkembang jauh lebih dahulu.

Gambaran tentang jawaban yang muncul dari informan terkait pertanyaan tersebut terlihat pada diagram 2 berikut. Data pada diagram 2. menunjukkan adanya tiga variasi 
jawaban di mana dari seluruh informan penelitian (16 orang), terdapat 9 orang yang menyatakan bahwa pandangan orang lain tentang istri menjadi buruh migran adalah pandangan yang biasa saja, kemudian 5 orang menjawab sebagai pandangan orang lain merupakan kritik sekaligus sebagai masukan yang berharga, dan terakhir 2 orang menyatakan sebagai pandangan yang seringkali membuat kesal.

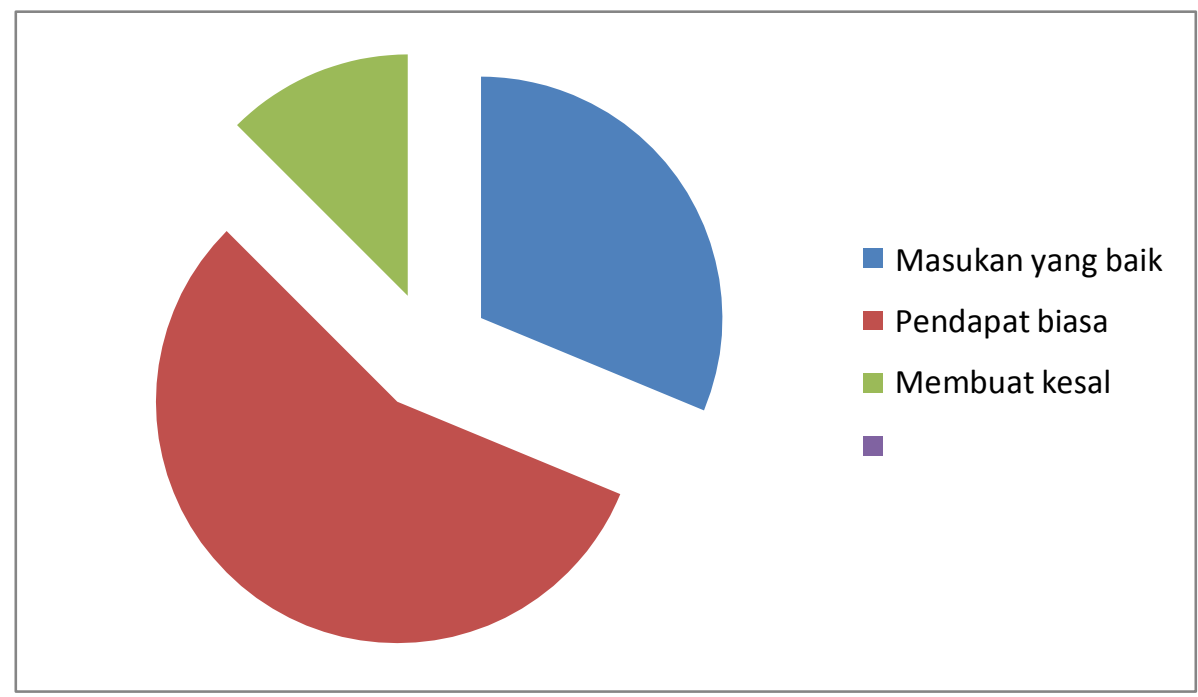

Diagram 2. Perspesi Informan terhadap Pendapat Orang lain Tentang "Istri Menjadi Buruh Migran" Sumber: Pengumpulan Data, 2015

\section{a. Pandangan Orang Lain adalah Pendapat Biasa}

Bagi sebagian besar informan, pandangan atau pendapat dari orang lain baik teman atau tetangga dianggap sebagai pendapat biasa saja, sebagai bagian dari proses interaksi sosial di antara sesama warga masyarakat. Mereka beranggapan bahwa merupakan hak bagi setiap orang untuk menyampaikan pandangannya tentang sesuatu, termasuk keberadaan istri sebagai buruh migran, ketika berinteraksi dalam lingkungan sosial.

Pandangan informan bahwa pendapat orang lain tentang istri menjadi buruh migran sebagai pendapat biasa saja berkaitan dengan pandangan dirinya tentang aspek yang sama. Informan yang memaknai bahwa pilihan istri bekerja sebagai buruh migran adalah pilihan yang biasa saja seperti pilihan jenis pekerjaan yang lain, seluruhnya menyatakan bahwa pendapat orang lain juga pendapat biasa. Sementara sebagian informan yang berpendapat bahwa pilihan pekerjaan istri sebagai buruh migran adalah pilihan yang juga beralih menyatakan bahwa pendapat orang lain sebagai pendapat biasa. Representasi tentang hal itu bisa dilihat dari jawaban yang disampaikan Nrd, 
“...orang lain ngomong apa pun soal bojoku...ya terserah, itu hak mereka. Kula ga mikirin soal itu, biasa saja, itu jadi bahan obrolan pas ngumpul-ngumpul. Orang kan ga tahu persis soal kita ...jadi ga masalah. Yang penting ...kula ngerti soal bojoku...”

Dengan pilihan seperti itu, mereka merespon pandangan orang lain dengan sikap yang biasa-biasa saja, sikap netral, terlepas dari pandangan orang lain itu positif atau negatif. Mereka menganggap bahwa hal itu merupakan bagian, bumbu, dalam obrolan sehari-hari dengan orang lain. Jawaban lain dari informan bisa dilihat dari potongan wawancara dengan Bsr berikut ini:

Peneliti: Kalau teman atau tetangga membicarakan istri Bapak, bagaimana tanggapan Bapak?

Informan: Maksudnya gimana, Pak, kula ga ngerti...

Peneliti: Jika mereka ngomongin istri Bapak, baik atau buruk, apa Bapak merasa tersinggung atau bagaimana?

Informan: Oh gitu...kula sih ga apa-apa, biasa bae, toh di sini soal itu sudah biasa, Pak. Banyak bojoe yang jadi TKW. Kadang kita memang ngobrolin soal itu pas ngumpul-ngumpul...y y bumbu obrolan lah

Peneliti: Lalu bagaimana tanggapan Bapak setelah itu

Informan: Kula sih ga mikirin itu...masih banyak soal lain, Pak, anak, Kerjaan rumah...kan kula ngerti keadaan bojoku. Selama ga masalah ya tenang aja...

\section{b. Pandangan Orang Lain merupakan Masukan Yang Berharga}

Data pada diagram 2. menunjukkan bahwa terdapat 5 informan yang menyampaikan pendapat bahwa pandangan orang lain tentang keberadaan istri menjadi buruh migran adalah pandangan yang bermanfaat. Mereka beranggapan bahwa pandangan tersebut merupakan salah satu bentuk kepedulian dan perhatian teman atau tetangga terhadap keluarganya, khususnya istrinya Mereka merasa bahwa pandangan tersebut merupakan masukan yang berharga untuk mengingatkan agar selalu hati-hati dan waspada terhadap segala kemungkinan munculnya masalah.

Mereka akan merspon pandangan dari teman atau tetangga, terlepas pendapatnya baik atau buruk, dengan sikap positif. Mereka menjadikan berbagai pandangan tersebut untuk selalu waspada dan selalu mengikuti perkembangan istrinya di luar negeri sebaik mungkin, antara lain dengan selalu menjaga komunikasi dengan istri sebaik mungkin.

Beberapa jawaban dari Sl, Tnt, dan Nrj di bawah ini bisa mewakili pandangan mereka. “...pendapan teman ya penting lah, kula jadi dingetin biar ngecek terus bojoku. Kasihan kan di negeri orang kalo dapat masalah..." 
“..kula karo kancaku memang sering ngobrolin masalah bojoe...ya sesama 'duda Arab', saling kasih masukan, siapa tahu ada masalah. Kalao ada kita obrolin juga, baiknya gimana...rasanya ada tempat buat curhat lah.."

“...bagi aku sih, temen dan tetangga itu peduli, mereka ingin bantu...ya dengan ngasih saran atau apa lah. Aku juga kadang ngasih saran ke yang lain, apalgi jika mereka tanya-tanya..."

\section{c. Pandangan Orang Lain Membuat Kesal}

Kategori pilihan terakhir, yaitu pandangan orang lain tentang istri menjadi buruh migram seringkali membuat kesal dinyatakan oleh 2 informan. Mereka beranggapan bahwa keputusan mengizinkan istri untuk menjadi buruh migran adalah keputusan keluarganya, sehingga masalah dan resikonya juga menjadi tanggung jawab keluarganya. Mereka menganggap orang lain baik teman atau tetangga hanya 'usil' saja, ingin ikut campur urusan orang lain. Mereka sebenarnya ingin menyampaikan kepada orang lain yang 'usil' itu bahwa ia mengambil keputusan migrasi pun karena terpaksa berkenaan dengan situasi dan kondisi ekonomi keluarga.

Dua orang informan, yaitu Srm dan Skd, merespon pandangan orang lain dengan sikap negatif. Mereka seringkali kesal dengan orang lain yang sepertinya ingin ikut campur masalah keluarganya. Jawaban dari Srm ketika ditanyakan tentang hal tersebut adalah:

“...gimana ya, Pak, kula sih ga suka orang ikut campur, nanya-nanya soal bojoku, apa urusannya ya. Sering kesel sih soal itu. mereka kan ga tahu juga masalahnya kayak apa..."

Sementara Skd, ketika ditanyakan hal yang sama, ia menjawab sebagai berikut:

“...soal kula karo bojoku itu masalah keluarga, ga perlu orang lain tahu. Pingingnya sih diurus sendiri, toh ga ganggu orang lain. Toh bojoku jadi TKW juga, kita putusin bareng karo bojoku..."

Hasil penelitian menunjukkan bahwa jawaban suami informan berkenaan dengan persepsi mereka tentang "istri menjadi buruhh migran" dan peresepsi mereka terhadap pandangan orang lain tentang "istri menjadi buruh migran" didasarkan pada beberepa pertimbangan dan sekaligus mempunyai tujuan tertentu. Perilaku suami buruh migran dalam kehidupan sosialnya merupakan fenomena yang disebut tindakan sosial, sebagaimana dikatakan Weber. Tindakan sosial, menurut Max Weber (dalam Turner, 2000: 17), adalah tindakan manusia yang dapat mempengaruhi individu-individu lainnya dalam masyarakat serta mempunyai maksud tertentu; suatu tindakan sosial adalah tindakan yang dilakukan dengan mempertimbangkan perilaku orang lain dan berorientasi pada perilaku orang lain. 
Tindakan sosial terjadi ketika individu melekatkan makna subjektif pada tindakan mereka. Manusia melakukan sesuatu karena mereka memutuskan untuk melakukan itu, untuk mencapai apa yang mereka kehendaki. Setelah memilih sasaran, mereka memperhitungkan keadaan, kemudian memilih tindakan. Tindakan sosial merupakan awal dari sebuah interaksi sosial.

\section{Kesimpulan}

Sebagai individu, suami buruh migran di Kecamatan Sliyeg Indramayu mempunyai karakteristik yang unik dan spesifik. Mereka membangun dan mengembangkan perilaku dalam kehidupuan sosialnya dengan mengonstruksi secara kolektif suatu 'dunia' kehidupan sosial nyata di sekitarnya, berkenaan dengan ketiadaan istrinya yang sedang menjadi buruh migran di luar negeri. Setiap fenomena yang dilihat atau dialami oleh mereka akan, selama istrinya menjadi buruh migran, tersimpan dalam ruang kesadaran diri dan berwujud sebagai pengalaman subjektif masing-masing individu.

Keputusan migrasi, dalam artian mengizinkan istri untuk menjadi buruh migran di luar negeri, yang dilakukan suami buruh migran sebagai informan merupakan sebuah tindakan sosial. Mereka menunjukkan sebuah perilaku tertentu yang secara subjektif individual maupun secara komunal sebagai kelompok (komunitas) memiliki makna tertentu, yang ditujukan kepada orang lain sehingga menerima makna yang sama. Di sisi lain, melalui interaksi dengan lingkungan sosialnya, perilaku suami buruh migran bisa dimaknai sama atau berbeda oleh sesama mereka atau warga masyarakat lain di luar mereka.

Pilihan mengizinkan istri menjadi buruh migran di luar negeri telah membawa dampak terhadap relasi-relasi domestik yang terjadi dalam keluarga, termasuk di dalamnya relasi suami-istri, relasi suami-anak, relasi istri-anak. Kepergian istri dalam waktu yang lama (minimal satu kali kontrak selama dua tahun) telah membuat berbagai peran dalam keluarga yang seharusnya dibagi antara suami, istri, dan anak akhirnya dilakukan secara rangkap oleh suami/bapak/ayah. Pilihan tersebut sejalan dengan pemaknaan mereka tentang keberadaan istrinya yang saat ini menjadi buruh migran. 


\section{DAFTAR PUSTAKA}

A. Buku

Berger, Peter dan Thomas Luckmann. 1969. The Social Construction of Reality: A Treatise in the Sociology of Knowledge. Garden City, NY: Doubleday

Creswell, John W., 1998. Qualitative Inquiry and Research Design: Choosing Among Five Tradition. New York: sage Publications Inc. USA

DeVito, Joseph A., 2000. Human Communication. New York: Longman, 8th edition.

Mulyana, Deddy. 2001. Metode Penelitian Kualitatif: Paradigma Baru Ilmu Komunikasi dan Ilmu Sosial lainnya. Bandung: PT. Remaja Rosdakarya.

Rakhmat, Jalaluddin. 2005. Psikologi Komunikasi Edisi Revisi. Bandung: PT. Remaja Rosdakarya

Turner, S.P. (ed). 2000. The Cambridge Companion to Weber. New York: Cambridge University Press.

B. Sumber Lain:

Badan Pusat Statistika Kabupaten Indramayu, 2014. Indramayu Dalam Angka Tahun 2014.

Badan Pusat Statistika Provinsi Jawa Barat, 2014. Jawa Barat Dalam Angka 2014.

Devi Rahayu. 2011. Perlindungan Hukum bagi Buruh Migran Terhadap Tindakan Perdagangan Perempuan.

Dian Noeswantari, dkk. 2011 Mencegah Trafficking melalui Prosedur Penempatan dan Perlindungan Tenaga Kerja Indonesia. Pusat Studi Hak Asasi Manusia, Universitas Surabaya.

Imam Rosadi. 2010. "Konsekuensi Migrasi Internasional terhadap Relasi Gender (Studi tentang buruh migran internasional yang pulang dari bekerja di luar negeri di Kecamatan Juntinyuat, Kabupaten Indramayu, Jawa Barat)”. Disertasi Universitas Indonesia. 